\title{
The situation of horticultural family farms in Hajdu-Bihar County
}

\author{
Nagyné Demeter, $D$. \\ Centre for Agricultural Sciences and Engineering, University of Debrecen 138 Böszörményi St., \\ 4032 Debrecen, Hungary
}

\begin{abstract}
Summary: The main aim of this research work is to study horticultural farms in Hajdú-Bihar County, that mobilize labour and capital for the sake of agricultural production, namely family farms. During this study work we tried to chart the main characters, the conditions of functioning, their profitability and its use possibilities, their external contacts and the resource of information of these farms, beside this to investigate the relationships between these parameters. Parallel to this we tried to compensate the relatively high deficiency of information by empirical research work. This deficiency is the characterization of farmers and the inducement of farming and its conditions both on the level of county and state. By our empirical research work we have made a comprehensive position paper that shows the conditions of farms and farmer populations, as well. Two hundred questionnaires were evaluated. The percentages of horticultural farms were $25 \%$ from all questionnaires. Above all this paper is looking for the answer to the following questions: How and by which sources do farmers develop and extent their farms? How do farmers see their own future, what kind of aims do they have? Who will stop and who will go on producing? The collected information on the whole may help to make much more flexible legislatives and administrative regulations, although the survey covered only one county.
\end{abstract}

Key words: family farms, income production, profitability, maintenance of the farmlands

\section{Introduction}

The main aim of this research work is to study farms in Hajdú-Bihar County that mobilize labour and capital for the sake of agricultural production. During this study work we tried to chart the main characters, the conditions of functioning, their profitability and its use possibilities, their external contacts and the resource of information of these farms, beside this to investigate the relationships between these parameters. Parallel to this we tried to compensate the relatively high deficiency of information by empirical research work. This deficiency is the characterization of farmers and the inducement of farming and its conditions both on the level of county and state. The collected information on the whole may help to make much more flexible legislatives and administrative regulations, although the survey covered only one county.

In the Agricultural Economical Research Institute deals for almost two decades with the investigation of farming circumstances and conditions, just as with the - indirect or emphasized - investigation of the farmers' opinion and reactions (Alvincz \& Varga, 2000; Kaproncai, 2005; Alvincz, 2001, 2003; Tóth \& Hamza, 2006). The methods and aims of our research work match the publications of the Research Institute in many aspects. They presume a full-developed research methodology and give us the opportunity to compare the representative national results with our conclusions.

\section{Material and methods}

The sampling area - Hajdú-Bihar County - is located in the North Great Plain region. This region is the second largest planning and statistical region (after the South Great Plain region) in Hungary in aspect of the area $\left(17729 \mathrm{~km}^{2}\right)$ and population it (1559 million people). The selection of the sampling area was supported by the fact, that the individual farming is the most typical in this region.

In this work we used two methods: primer and secondary data-collection. The resources of the primer data-collection were the questionnaires of our empirical survey that have been completed by the relevant information from informal interviews with farmers (who previously filled the questionnaires in. Beyond the questionnaire survey other informal interviews were made. These were colloquies, talks about profession, not standardized interviews. The objects of these informal interviews were mainly family farmers previously asked in the questionnaires. In addition we also had colloquies with people from offices, the chamber of agriculture and the members of the local farming advisory board.

We introduced and analysed the nearer (on the level of the county) and the wider (on the level of the region) farming conditions by the secondary data. The databases in the survey rest on databases of the TeIR (National Land Development and Land Arrangement Information System) and T-Star, just as the collected and processed secondary data of the $\mathrm{KSH}$ 
Table 1. The characteristic of sample

\begin{tabular}{|llc|}
\hline & Category & Distribution in sample (\%) \\
\hline sex distribution & Men & 81,5 \\
& Women & 18,5 \\
\hline time of agricultural & $>10$ years & 66,0 \\
production & 5-10 years & 24,5 \\
& $<5$ years & 9,5 \\
\hline Kind of agricultural plant production & 51,5 \\
production & horticulture production & 48.5 \\
& from this & (25\% of total sample) \\
& animal husbandry & 11,5 \\
& mixed & 37,0 \\
\hline Education & non professional higher education & 5,5 \\
& professional higher education & 29,0 \\
& secondary non technical school & 18,0 \\
& secondary technical school & 34,5 \\
& basic school & 13,0 \\
\hline Farming state & full-time job & 57,0 \\
& part-time job & 10,5 \\
& full-time job in their free time & 17,0 \\
& pensioner & 12,5 \\
& unemployed & 3,0 \\
\hline
\end{tabular}

$\mathrm{N}=200$

Source: On the basis of empirical research self-edited

(Central Statistical Office). The data of the General Agricultural Draft (ÁMÖ) in 2000, just as of the economy structure drafts (GSZÖ) in 2003, 2005 and 2007 have been processed in this work more emphasized.

The studied population consisted of farms from HajdúBihar county that are larger than 1 hectare, the main leader is the in the questionnaire asked farmer and he owns the gross of the fixed and liquid assets so he has an own farmland. The target population was chosen from the in the database of KSH registered agricultural, wild management, fish farming active farms, as sampling abundance. The people who filled the questionnaire were selected by random simple sampling, trying to reduce the subjectivity of sampling to a minimal level. The number of filled out and evaluated questionnaires was 200. By the composition of the questions both qualitative and quantitative methods have been used. The characteristic of sample are represented in Table 1. The data of the survey were evaluated by SPSS 13.0 for Windows software, the figures were made by Microsoft Office Excel 2003 and the maps were edited by GeoMedia Professional 5.1 computer program.

\section{Results and discussion}

Regarding the distribution between different agecategories of the in the research work involved people a relative high homogeneity could be observed. The youngest was 21, while the eldest 78 years old. The average age of the involved people was 47.5 years, that is favourable than the average in the county. More than $60 \%$ of the involved answerers belong to the age group 35-55. It is favourable; still the rate of people under 30 was only $5.5 \%$ that is a rather negative for the future perspectives. Or rather it confirms our hypothesis that faming - as a life-style - is not too attractive for the younger generations and its social prestige is quite low. It was also stated in our survey that the farmer population is getting even older, that means henceforward a problem. The social judgement of farming as a life-style doesn't help either the development of farming identity. Farmers themselves consider that agricultural production compared with other income facilities means a rather more negative possibility. It hinders the harmonisation of the dual production structure in a long-term period (Figure 1).

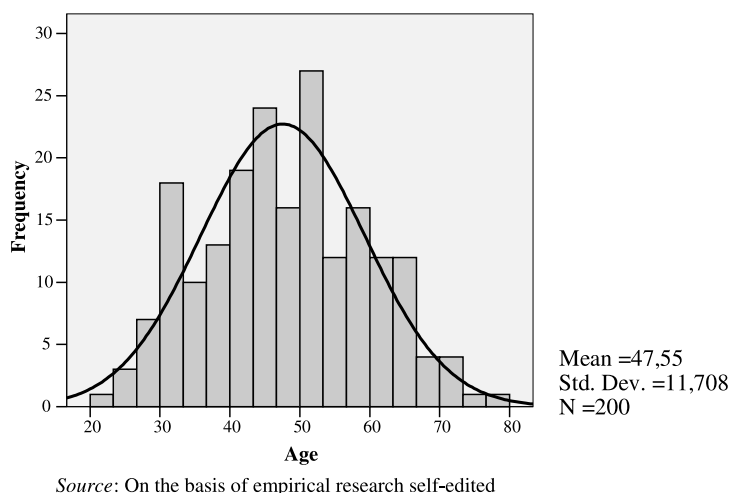

Figure 1. The distribution of involved answerers between different age-groups, regarding the frequency of the valid answers, 2008

Farmers are not tending to choose the potential their additional incomes related close to agricultural production or to activities connected to rural lifestyle. Therefore, the secondary activities connected to rural lifestyle shall be reconsidered in the future. The so far preferred village tourism and the handicraft are not viable in this region. Dominating activities related to commerce and services give them a new possible way in the future. Beside the income diversification based upon real needs the territorial differences that are present from some decades should be considered as well.

Farmers consider that the most important is to maintain their farmlands; therefore farming is not a temporary activity, but a long-term life-style. The availability and effectiveness of sources for that has a major effect on their future. Subventions from applications have higher importance in farming than credits, that's an important fact. It's true, although farmers also consider crediting practice to be favourable.

\section{Income production and utilization}

The life-style that the family can afford to from its income is also in connection with the issue of income. Adjusting the profitability of farmers we didn't measure profit production upon indexes with absolute numbers (income, liquidity rate etc.) like it is done in practise, but upon the subjective opinion and rate of farmers. In most cases of farmlands the income (from farming) makes out more than $75 \%$ of the family income. Regarding the frequency of mentioned cases the next category is the income 
rate of $25-50 \%$, followed by the answer category of the smallest income rate. The distribution of categories in function of the farming state shows a statistically significant relationship $(\mathrm{p}=0.000 ; \mathrm{p} \leq 0.05)$. As a result of the empirical research work we defined new status types of family farms according to the income from agricultural production. More than $50 \%$ of farmers ranked to the income rate category between $50-75 \%$. Therefore it can be stated that to be a fulltime producer farmers have to gain more than the half of their income from agricultural production. None of the members of not full-time producing groups are ranked to the highest category, most of them are somewhere under the rate of $50 \%$ (Figure 2).

It is a positive phenomenon that in the category $50-75 \%$ the rate of groups that are not full-time workers is rather similar. Accordingly, agricultural production is a relative profitable activity; families rate them as important income source. The role of agricultural production in the income compensation seems to be confirmed. The rate of profitability in also related to the operation priorities of the farmland. In farms where the development is objected the profitability is more positive. It is primarily due to the fact that mainly full-time farmers have chosen this aim. "Sober minded" farmers, who object rather the maintenance of their farmlands rate their profit much more moderate, while the number of farmers who rate their farmlands deficient is quite high. This group consists of mainly pensioners and part-time workers. Still, it is a positive phenomenon, that despite all they don't want to give agricultural production up. It confirms that farmlands survive crises in a relative high extent and that production plays an important and fix role as additional income.

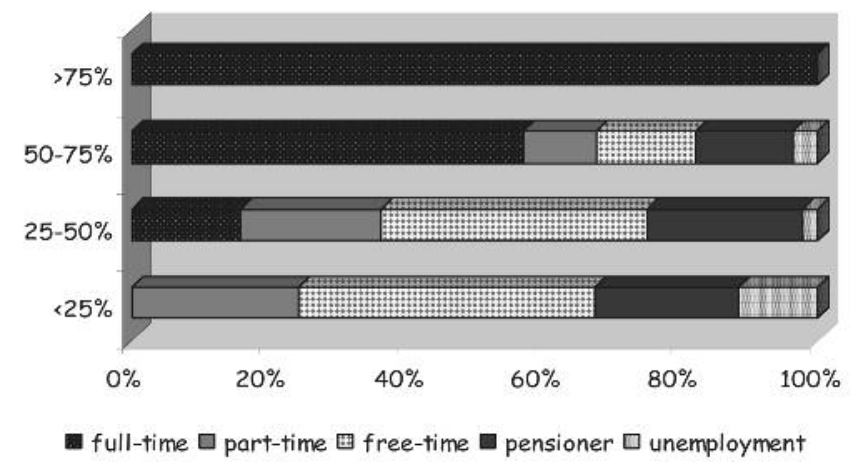

$\mathrm{p}=0,000, \mathrm{p} \leq 0,05$

Source: On the basis of empirical research self-edited

Figure 2. Distribution of farmer states in function of the income rate from agricultural production, in function (\%) of the valid answers, 2008

The European Union supports agricultural producers and income diversification of rural people in a long-term. In case of this issue we got rankling results: $24.5 \%$ of farmers do any other by-activity. The external income source - unlike its animating role in the middle of the $90 \mathrm{~s}$ - can be rated nowadays as "escape". Farmers try to choose their potential income compensating, supplying sources not closely related to agricultural production or rural life. This fact calls our attention to the lack of by-activities and the low undertaking activity. Unbalanced market circumstances and realization problems have lead to mistrust against the branch; farmers don't rate the offered and supported by-activities as profitable. Therefore the activities connected to rural life should be revised in the future. The up till now preferred village tourism and handicraft are not viable in this region. The dominance of activities related to trade and services can give them a new and reasonable way. Beside the income diversification upon real demands should be the for more decades present regional differences taken into consideration. Last but not least we asked - in the issue of profit production and utilisation - how farmers see their profit in the next three years. The rate of the answers in this case was the same as the rate of answers in the issue of estimation of the farming profitability. The latter case there is a significant relationship $(\mathrm{p}=0.01 ; \mathrm{p} \leq 0.05)$. The most of them (42\%) made stagnation the most probable. Almost the same number of answerers has named better and worse profitability expectations. Regarding the mistrust and pessimistic answering approach of farmers the arguments by the stagnation can be rated as positive phenomenon.

\section{“Through a glass, darkly" - Future}

The judgement about the future of agricultural production depends on many factors. Unfortunately we didn't have the opportunity to deal with all of them within the confines of our research work. Future means for farmers mostly their future plans with their own farmlands. Farmers consider the maintenance of the farmlands is the basic plan for the future. So in their opinion farming is not only a permanent activity, but a long-term life-style. We also compared the farming state with farming priorities and found - in a not surprising way - a very close relationship between the two factors. The maintenance of the farmlands was an aim in the highest rate in case of pensioners and part-time workers. But the selfsupply was an aim by the free-time workers, while development was the most important objective in case of fulltime farmers. We found an unambiguous relationship between the long-term aims and the form of the production. Family farms showed the most balanced picture: their aim was mostly the further farm development, beside this the harmonisation of consumption, maintenance and development. The future plans of farms and the priorities of the activities determine basically the growth of the farm size. In farmlands, where the aim is the development and the harmonised operation, the size of the estates grows in a huge rate. The more positive the future plans are, the cropland area was extended in a higher rate during the past three years (Figure 3).

The sources and their utilisation for these aims have capital importance for the future. The resort to credit was independent from age or education. Still it is interesting that the lowest amount of credit was taken by the members of the basically educated group (23\%); this group was followed by the group of higher - but not professional - educated farmers 


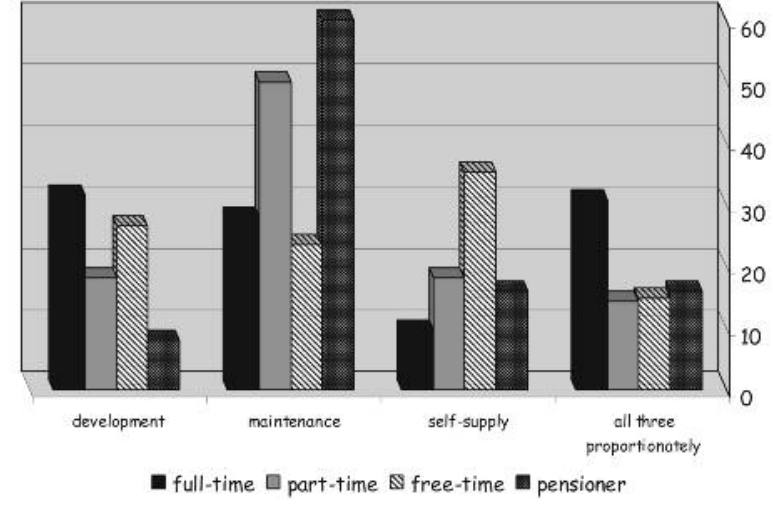

$\mathrm{p}=0,000, \mathrm{p} \leq 0,05$

Source: On the basis of empirical research self-edited

Figure 3. Relationship between farmer status and priorities, in the distribution of valid answers, 2008

(27\%). The highest and lowest educated farmers resorted to credit in almost the same extend. The involvement of credits as external means for the maintenance and development of the farms was typical in case of the full-time farmers; therefore it depends on the status of the farmer.

The willingness of farmers to get credits is independent from the duration and type of the farmland; still it is worthy of note that there is a statistically significant relationship between the income rate (from agricultural production) and the willingness of farmers to get credits $(\mathrm{p}=0.00 ; \mathrm{p} \leq 0.05)$. The credit uptake highly depends on the operating priorities of the farmland; of course farmers who objected development and harmonisation of their farmlands took more credit up recently. Credit is henceforward not the primer source for development for individual farmers. It is an important fact that the role of supplements from applications is higher than that of credit. It is true, although the credit uptake process is favourable in the farmers' opinion as well. Upon the results of the survey it is not surprising that the aims of the farm are closely related $(p=0.01 ; p \leq 0.05)$ to the willingness to apply for additional sources; the highest activity was measured in the group of farmers who object to develop their farmlands or harmonise the production aims.

According to the farmers' opinion the applications are basically important for a successful production. In contrast to the credits, farmers consider applications to be basically important for the successful production. This fact indirectly confirms their lack of capital, and that marketing anomalies make (the anyway risky) agricultural production and its income unpredictable. It's totally different from the situation of ten years before, whereas farmers gained their sources for development mainly from family members or other people and from external income sources. Attitude of family farmers will have a main role in the tendency of future prospects. These attitudes strongly depend on grower's sense: How secure the market and functional circumstances of growing production? Several, different studies have related that there is a main factor, which is very importance for wide levels of society: the relation to safety (Simon, 2005).

Two decades after the economical and social change it seems to be sure, that the configuration of a transparent, welloperating production structure has failed. The problems connected to the agricultural production are often related to disarranged circumstances. For this situation many of the segments have their own responsibility. The failures of the privatisation law (e.g. to gain estate without any equipment, the recompensation that lead to the subdivision of estates), a dynamically changing market, the too high or even too low evaluation of the social and economical role of the branch, and the ambivalent matching to the often different expectations and norms all assisted to the fact that both political leaders and farmers see the situation of farming "through a glass, darkly" at present and in the future.

\section{References}

Alvincz, J. \& Varga, T. (2000): A családi gazdaságok helyzete, versenyképességük javításának lehetőségei. Agrárgazdasági Kutató és Informatikai Intézet, (15): 86.

Alvincz, J. (ed.) (2001): A mezőgazdaság jövedelemhelyzete és az arra ható tényezők. Budapest, Agrárgazdasági Kutató és Informatikai Intézet, (7): 7-11.

Hamza, E. \& Tóth, E. (2006): Az egyéni gazdaságok eltartó képessége, megélhetésben betöltött szerepe. Budapest, Agrárgazdasági Kutató és Informatikai Intézet, (2): 85.

Huzsvai, L. (2004): Biometriai módszerek az SPSS-ben. SPSS alkalmazások. Egyetemi jegyzet. Debrecen, DE MTK, 158. p.

Kapronczai, I. (ed.) (2005): A mezőgazdasági termelők alkalmazkodóképességének jellemzői (Gazdálkodói válaszok időszerű kérdésekre). - Agrárgazdasági Tanulmányok. 2005/6. Budapest, Agrárgazadsági Kutató és Informatikai Intézet, 89. p.

Simon, S. (2005): A mezőgazdaság periferizálódásának elméleti háttere (In: Az Európai Unió bővítésének kihívásai - régiók a keleti periférián. Ed.: Nagy, E., Nagy, G.) Békéscsaba, Nagyalföld Alapítvány, 70-74. p. 